\title{
A Study Into the Possibility of Upgrading Farmers' Profit by Means of Linking Small Holder Farmers to Potential Market Chain
}

\section{Taye Beyene Lemma}

Adami Tulu Agricultural Research Center, Zeway, Ethiopia

\section{Email address:}

tayebeye@yahoo.co.uk

\section{To cite this article:}

Taye Beyene Lemma. A Study Into the Possibility of Upgrading Farmers' Profit by Means of Linking Small Holder Farmers to Potential Market Chain. International Journal of Business and Economics Research. Vol. 4, No. 4, 2015, pp. 192-200.

doi: $10.11648 /$ j.ijber.20150404.12

\begin{abstract}
The study was conducted in Bennekom and Wageningen (the Netherlands) to link the spelt grower farmers to potential market chain. For this study purpose, two village towns were selected using purposive sampling techniques. From the selected area, a total of 60 respondents were randomly selected and interviewed using structured questionnaires and check list. Data were collected and analyzed using appropriate statistical packages for social sciences (SPSS) software of version 20.In analyzing stakeholders and market institutions, a chain mapping was used to determine the relationship and arrangements that exist among actors in the chain. The study results revealed that the spelt bread value chain in Bennekom and Wageningen consists of organic and conventional segments. It is market driven and a short chain that only few actors are involved. There is a good opportunity for farmers, millers and bakers to align themselves to create a local conventional spelt bread chain where farmer, the least actor gaining profit from his own product can optimize his income. Spelt growers, millers and bakers should cooperate in order to formulate a sustainable profit-oriented chain that supports the goal of the Stichting Buurstchap Doesburger Eng (SBDE) foundation in upholding social cohesion in Doesburger Eng area. To make these possible, farmers should be linked to millers and bakers who will process their spelt to flour and bread respectively. However, in this chain where relationship is based on trust and not on contracts, the farmers should be able to fulfill the requirements of delivering consistent good quality and supply of flour throughout the year which serves as the foundation of building trust among partners in the chain.
\end{abstract}

Keywords: Bread, Spelt, Stakeholders, Value Chain

\section{Back Ground and Justification}

Spelt is a grain that is in growing demand for food-grade milling. It is a subspecies of wheat, and is sometimes used in livestock feed as well. A wonderfully nutritious and ancient grain with a deep nutlike flavor, spelt is a cousin to wheat that is recently receiving renewed recognition. Its heritage traces back long before many wheat hybrids. Many of its benefits come from the fact that it offers a broader spectrum of nutrients compared to many of its more inbred cousins in the wheat family. It can be used in many of the same ways as wheat including bread and pasta making (WHFoods, 2012).

Spelt features a host of different nutrients. It is an excellent source of manganese, and a good source of protein, copper, and zinc. As the genetic makeup of spelt is different to wheat, it is a grain that many people who are sensitive or allergic to wheat can use. Spelt does contain gluten but overseas studies have shown that it can be tolerated by many people who are normally gluten-intolerant. The reason given for this is that the larger quantities of available protein found in spelt are soluble and, therefore, can be easily assimilated by the body with the minimum of digestive work. Results of routine allergy testing in both the US and the UK have also shown that when many wheat sensitive individuals are exposed to both wheat and spelt the majority react negatively to the wheat sample only (FAO, 2003).

It falls into the niche product and is important in specialty breads, organic food and food products with characteristics that differ from regular wheat products (Ranhotra et al., 1995, Schober, Bea n, \& Kuhn, 2006 as cited by Escarnot 2010).

Spelt features a host of different nutrients. It is an excellent source of manganese, and a good source of protein, 
copper, and zinc. As the genetic makeup of spelt is different to wheat, it is a grain that many people who are sensitive or allergic to wheat can use. Spelt does contain gluten but overseas studies have shown that it can be tolerated by many people who are normally gluten-intolerant. The reason given for this is that the larger quantities of available protein found in spelt are soluble and, therefore, can be easily assimilated by the body with the minimum of digestive work. Results of routine allergy testing in both the US and the UK have also shown that when many wheat sensitive individuals are exposed to both wheat and spelt the majority react negatively to the wheat sample only (FAO, 2003).

The crop has the lowest yield of 2.6 tonnes compared to barley, triticale and rye which have $6.3,5.6$ and 4 tonnes respectively. (Wageningen University Research, 2012 as cited by Verschuur 2012). The maximum flour yields of spelt obtained at $100 \mathrm{~g} / \mathrm{kg}$ grain moisture content is approximately $78 \%$ and comparable to common winter wheat which is at $82 \%$ (Abdel-Aal and Huci, 2005).It is therefore a more sustainable crop on a long term basis.

Being low yielding it also thrives without the application of fertilizers even on relatively poor soils. Spelt is also very resistant to frosts and other extreme weather conditions and the grain's exceptionally thick husk protects it from pollutants and insects. As spelt is a pure, original grain and not biologically modified in any way it is very resistant to the crop diseases that often plague modern crop varieties and grows quite successfully without the application of herbicides, pesticides or fungicides (NCSU, 2005).

Spelt is one of the cereal crops cultivated in Doesburger Eng in Ede. Currently, few farmers remained growing spelt as the others previously planting the crop shifted to maize due to low profitability of the crop. Some farmers want to preserve spelt cultivation due to its historic background. However, aside from low yield, they have problems on how and where to market their product with a higher profit. The loss incurred in farmers' farm business has made their farming unsustainable. At present, they are supplying to a mill close to their farm which processes spelt for feedstuff. However, this has a low added value where profit is not optimized. In Doesburger Eng in Ede, even if identification of possibility of creates added value on spelt was conducted by Van Hall Larenstein University students but there is limited information on linking spelt grower farmers to potential market chain. From the previous study, a value addition is possible if spelt will be processed to bread. Peter et al (2015) also indicated that, farther processing raw materials to final products should be encouraged as an economic decision to wards high revenue generation. Therefore, this study attempts to investigate the feasibility on linking the small holder farmers to potential market chain.

\section{Materials and Methods}

\subsection{Study Site}

The study was conducted in Bennekom and Wageningen in 2013. Wageningen is situated on the North of Nederrijn and at the border between the Gelderse valley and the veluwe of which the south west hills called the Wageningen berg. According to the Wageningen municipality report of (2013), the population of the city is 37,432 . The town is home of three local bakeries where two of the three are producing local conventional spelt bread and one producing organic spelt bread. Bennekom is a village located between Ede and Wageningen (The Netherlands). It is a part of the Municipality of Ede in the south-west of the Veluwe district of the Province of Gelderland. It is the second largest village after the city of Ede with a population of approximately 15,000 . It has emerged as one of the early village structures (Dorpsraad Bennekom, 2012).The village is home of four local bakeries where two of five local bakeries are producing different types of breads namely Jop ten Veen and Broodbakkerij Bak and the rest are pastries. Wageningen and Bennekom were selected as the study site with the criteria of having large number of grain mills, bakeries and spelt bread consumers.

\subsection{Data Sources and Methods of Collection}

Both primary and secondary sources of data were used in this study. Secondary data were obtained from reports of the previous sustainable production study in Doesburgers Eng and published and unpublished materials to acquire necessary information and have an in depth understanding about the spelt production and bread processing. Primary data were collected using structured questionnaire, case study and direct observations. Purposive sampling techniques were employed to select 35 consumers, 14 chain actors, 3 spelt growers, 5 retailers, 3 value chain supporters and a total of 60 respondents. Then, interview was conducted with the selected respondents to generate the relevant data by using structured questionnaire survey and check list.

\subsection{Data Management and Statistical Analysis}

The collected data through survey were analyzed using appropriate statistical packages for social sciences (SPSS) software of version 20. In analyzing stakeholders and market institutions, a chain mapping was used to determine the relationship and arrangements that exist among actors in the chain. While the computation of gross income and value shares were used to compare values added in each actor and identify which segments in the chain is profitable. The Strengths, Weaknesses, Opportunities and Threats (SWOT) were used to provide an over-all picture of the features of the chain. In addition, CANVAS model was used for the generation of business idea.

\section{Results and Discussion}

\subsection{Spelt Bread Value Chain Features in Bennekom}

As shown on figure 1, there are two segments of the spelt 
chain namely organic and conventional. Due to the absence of local producer of spelt grains for human consumption within Bennekom, Ede and Wageningen, grains (organic segment) and flour (conventional) are sourced outside of the aforementioned areas.
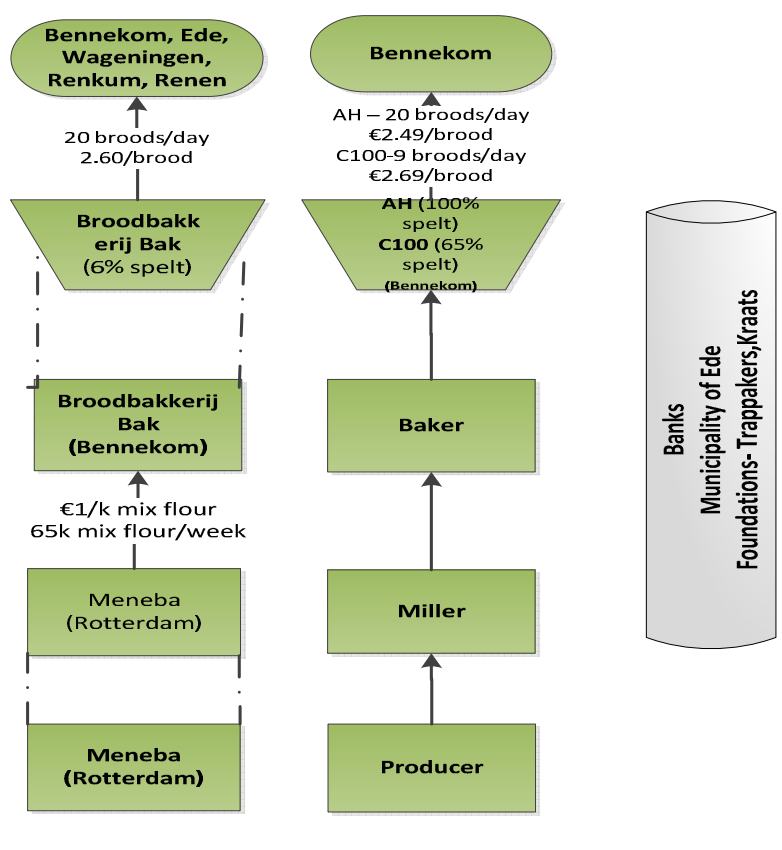

Supporters

Functions

Actors

Figure 1.Spelt Bread Value Chain in Bennekom.

\subsection{Spelt Bread Value Chain Actors in Bennekom}

\subsubsection{In Put Suppliers}

- Agrifirm: is a cooperative in with more than 17,000 Dutch farmers and horticulturalists members. It has approximately 100 years of existence and a result of a merger of old Agrifirm and Cehave Landbouwbelang. It offers high quality products like animal feed, seeds, fertilisers and pesticides. It is one of the suppliers of organic Skal certified spelt grains located in Almeer. Presently it is supplying grains to Molen de Vlijt at $€ 1 / \mathrm{kg}$.

- Meneba: is a European producer of grain-based ingredients for bakers and food, feed and non-food producers world-wide (Meneba, 2013). The Meneba in Rotterdam delivers mix flour made of spelt, quinoa, amaranth and wheat to Broodbakkerij Bak, which is sold at $€ 1 /$ kilo.

\subsubsection{Millers}

- Molen de Vlijt: is a Skal certified miller in Wageningen. It sources its organic spelt flour from Agri-Firm in Almeer. In a year, it orders an average of 18 tonnes of spelt that is gradually delivered monthly. About $50 \%$ of the grounded spelt grain is sold to the bakeries such as Stroop and De Niuwe Molen and 50\% are sold to customers in the mill site. It mills certified Skal cereals only. In addition, the milling service cost is $€ 30$ per hour at 200 kilos grains/hour. It can mill 200 kilograms of grains in an hour and has 35 silos which can store approximately 85 tons and thus offer storage facilities for grains. They also offer transport service of at least $€ 30-40 /$ delivery at 2 tonnes.

- De Nieuwe Molen: is a conventional miller in Veenendaal. It is owned by a foundation named The Utrecht Mills. Millers are on a voluntary basis. The wind mill grinds cereals for human and animal consumption and it also has a shop onsite where traditional ground flour products are sold. Tevens is de molen in gebruik voor de opleiding van nieuwe molenaars. The mill is also in use for the training of new millers. It supplies wheat, rye, and spelt flours to Joop ten Veen. However, the organic spelt flour is sourced from Molen de Vlijt and not grounded on their mill. It can mill 100 kilograms per hour.

\subsubsection{Bakeries}

- Joop ten Veen: is an artisan which has been around since 1951. It started with a grocery store and expanded it to bread and pastry. It prefers to use raw materials grown in the region in baking breads. They worked with local producers such as the Stitching Trap Akkers from Ede or The Kraats in Bennekom to create a local product for rye and wheat. They mill raw product at the De Nieuwe Molen. To them, "Local products are products with a specific name made in a particular area". It sells uncertified organic bread at 3.60/loaf.

- Broodbakkerij Bak: is a local bakery in Edesweg, 
Bennekom that produces 3,000 pieces of bread weekly with an approximately $80 \%$ loaf breads. Most of their bread are made of wheat, while $4 \%$ (120 loaves) is made of mix flour of spelt (6\%), quinoa, amaranth, wheat sold at 2.60/piece. The mix flour is sourced from Meneba in Rotterdam. The mix flour consumption of the shop is at 65 kilos/week.

The shop has customers from Bennekom, Wageningen, Renkum, and Ede. It does not deliver bread to other retailers because the volume produce/manpower is enough in the shop. The quality of the grains is the number one criteria for supplier of flour. The owner believes that there is a market for local products such as the spelt and that it promotes of the area as well. He would like to have a sample of the flour from the farmer and make it into bread to test the quality of the spelt.

- Stroop: is an organic bakery that is located in Wageningen. It delivers spelt bread to Kardoen (Bennekom) and Buys and Ko (Wageningen). They are sourcing 50 kilos/week of organic spelt flour from Molen de Vlijt.

\subsubsection{Spelt Product Retailers}

- Jop ten Veen: has two retail shops at in Dijgkraft and Eikenlaan while Broodbakkerij Bak has its own retail shop at the baking site.

- Kardoen: is a Skal certified organic shop located in Marktplein. It is retailing 100\% spelt brood and sources it from Stroop, Verbeek in Brummen, Netherlands and
Biobakker in Ahaus, Germany. In this report, Verbeek and Biobakker were not given priority discussion since the focus is on local spelt bread chain.

- Albert Heijn: is a market leader in the Netherlands and longstanding positioned as a full service grocery store. It has 33.5\% market share (Distrifood, 2013). It sells 100\% spelt bread at $€ 2.49 /$ loaf and at an average sale of 20 loaves per day.

- C100: is the number two player in the supermarkets with a market share of $12 \%$ in 2011 (Distrifood, 2013). It sells spelt bread that is made of $65 \%$ spelt at $€ 2.69$ per loaf and with an average sale of 9 loaves per day.

\subsubsection{Chain Supporters and Their Role}

Based on the interview at least one of the actors mentioned about a bank for a loan. While based on literature search, the foundations Stichting de Trapakkers from Ede and The Kraats in Bennekom facilitate the link between local producers of wheat and rye only to Jop ten Veen.

Another supporter of the chain is the local government of Ede who is currently promoting the idea of selling local products. Recently a website is being created and a feasibility study is conducted to on the profitability of using current closed shops at the centrum to display local products is on-going and funded by the municipality. The study is looking only at the involvement/arrangement between shopkeepers and local producers and how they will benefit.

\subsection{Spelt Bread Value Chain Features in Wageninge}

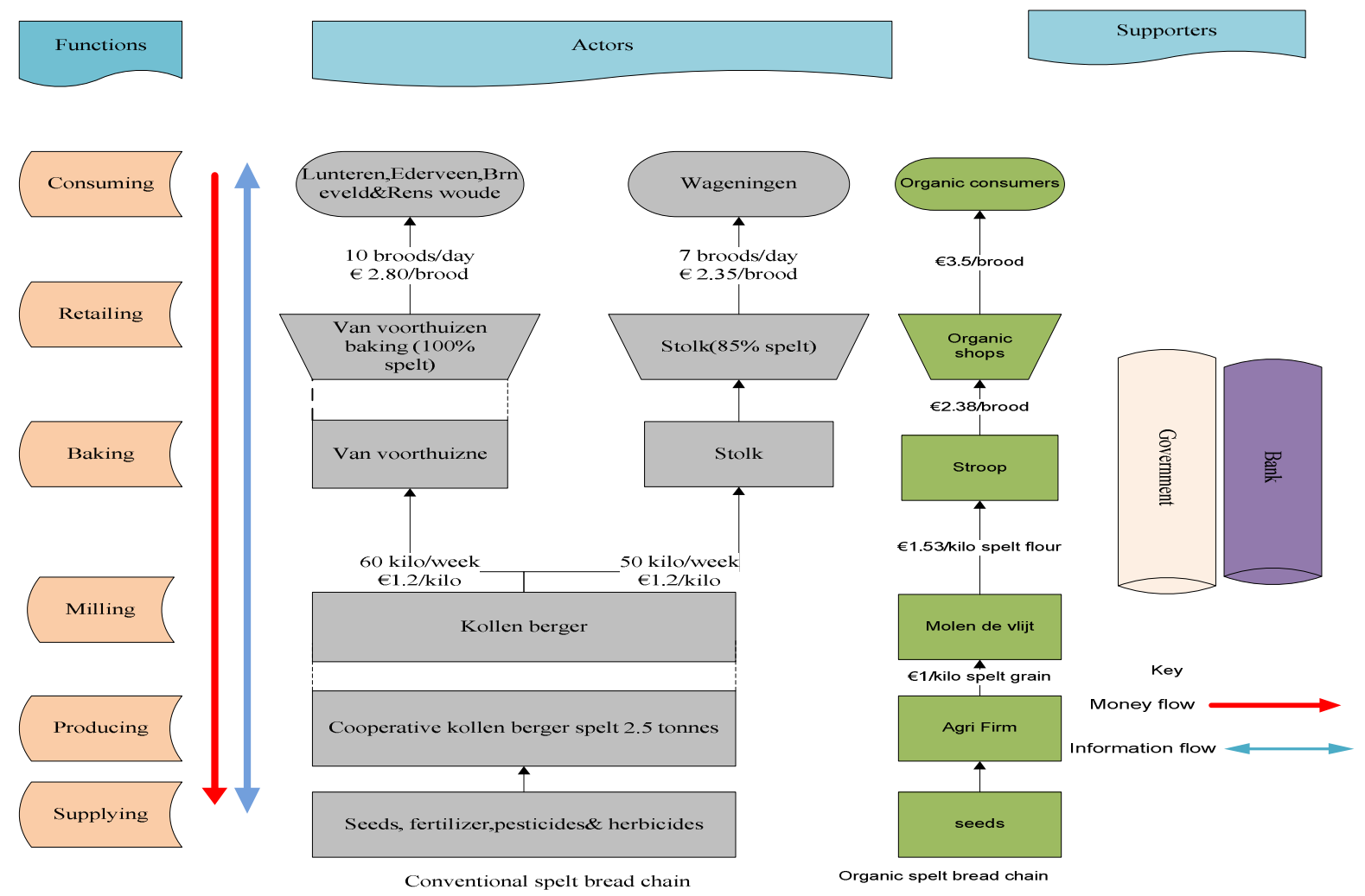

Figure 2. Spelt bread value chain in Wageningen. 


\subsection{Spelt Bread Value Chain Actors in Wageninge}

\subsubsection{In Put Suppliers}

- Kollenberger spelt: is a cooperative of spelt crop located in Limburg. This cooperative was established from teelers, millers, wholesaler flour and bakeries. Kollenberger spelt growers have years of experience with the cultivation of Limburg quality spelt. Currently it supplying conventional spelt flour to Voorthuizen and Stolk bakeries

\subsubsection{Millers}

- Op Hoop van beter: is a cereal miller located in Ingen, Netherlands. It is milling every day. This miller is willing to accommodate the whole grain spelt of $\mathrm{Mr}$. Maassen and proved transport service if necessary. It is milling $200 \mathrm{~kg}$ grain/hour with the price of $€ 30 / 100 \mathrm{~kg}$.

- De Nieuwe Molen: is a conventional miller in Veenendaal. It is owned by a foundation named the Utrecht Mills. Millers are on a voluntary basis. The wind mill grinds cereals for human and animal consumption and it also has a shop onsite where traditional ground flour products are sold. Tevens is de molen in gebruik voor de opleiding van nieuwe molenaars. The mill is also in use for the training of new millers. It supplies wheat, rye, and spelt flour to Joop ten Veen. However, the organic spelt flour is sourced from Molen de Vlijt and not grounded on their mill. It can mills 100 kilograms per hour. Moreover, in order to get high quality bread, protein is particularly important. This is the reason why the millers are also particular of the quality of the grains they are accepting from farmers as bakers also require them of quality flour. The miller gives the milling service to the farmers. The farmers have no direct contract with this miller. Bakers always contact the miller to mill the grain which they bought from the farmers.

- Molen de Vlijt: is a skal certified miller located in Wageningen town. Its organic spelt flour from Agri-Firm Company in Almeer. The miller order 18 tonnes of spelt grain annually and delivered monthly. About $50 \%$ of the grounded spelt grain is sold to the bakeries such as Stroop and De Niuwe Molen and 50\% are sold to customers in the mill site. The miller can mill $200 \mathrm{~kg} /$ hour with cost service $€ 30 / 100$ kilo and has 35 storage tower which can store approximately 85 tons.

\subsubsection{Bakeries}

- Bakery Van Voorthuizen: is a local conventional spelt bakery in Wageningen and has four modern retiling shops. The shops are found in Wageningen, Lunteren, Ederveen, Barneveld and Renswoude. The bakery is sourced spelt flour from the Kollenberger spelt and baking special bread $100 \%$ of spelt bread. It sells dark desembroodje $400 \mathrm{gm}$ by $€ 2.80$. An average 10 loaves of spelt bread per day and 30 per week are selling. It is also sell more and more products as spelt such as spelt crackers, granola spelt and eggs cakes

- Bakery Stolk: Is also a local conventional spelt bakery in Wageningen and produced 50 pieces of bread per week. The raw material is sourced from Kollenberger spelt cooperative in Limburg on the price of $€ 1.2 / \mathrm{kilo}$. The flour consumption is $50 \mathrm{kilos} /$ week. It sells 7 loaves of bread per day and 25 loaves of bread per week at $€$ $2.35 \backslash 400 \mathrm{gm}$.

- Stroop: is an organic bakery that is located in Wageningen. It delivers spelt bread to Kardoen (Bennekom) and Buys and Wageningen. They are sourcing $50 \mathrm{kilos} / \mathrm{week}$ of organic spelt flour from Molen de Vlijt.

\subsubsection{Spelt Product Retailers}

- Van voorthuizen: has four modern retailer shops at Lunteren, Ederveen, Barneveld and Renswoude. Every day, fresh bread is distributed to these shops and sells to the local consumers.

\subsubsection{Chain Supporters and Their Role}

Based on the interview result bank and Wageningen municipality are the supporter of spelt bakers and millers but based the literature of previous sustainable production study in Doesburgers Eng, SBDE foundation who facilitates the sustainable restoration of the Doesburger Eng to its original status which is its primary goal of coordination of regional development.

\subsection{Spelt Stakeholder Analysis}

Table below shows the stakeholders who are directly and indirectly involved in the chain. For their specific roles, certain issues and barriers are also presented hindering in one way or another their contributions in the chain. The stakeholders are categorizing into three: primary stakeholders, secondary stakeholders and tertiary stakeholders.

Table 1. Spelt bread value chain stakeholder analysis matrix.

\begin{tabular}{|c|c|c|}
\hline Stakeholders & Interests and Expectations & Barriers and Issues \\
\hline 1. Primary & & \\
\hline Farmer & farm management & low productivity and profit, poor market access \\
\hline Miller & $\begin{array}{l}\text { processing/milling } \\
\text { consistency in supply and quality }\end{array}$ & protein content, hygiene \\
\hline $\begin{array}{l}\text { Baker } \\
\text { 2. Secondary }\end{array}$ & baking, production of end product (breads) & Reliable supply of flour, quality \\
\hline $\begin{array}{l}\text { Seed companies } \\
\text { Roekel }\end{array}$ & $\begin{array}{l}\text { Supply of seeds for planting } \\
\text { delivery of seeds, transport and 'combine' machine for postharvest }\end{array}$ & Cost of service \\
\hline
\end{tabular}




\begin{tabular}{lll}
\hline Stakeholders & Interests and Expectations & Barriers and Issues \\
\hline & processing & \\
Test laboratories & quality check of grains & weak communication with farmers \\
3. Tertiary & social cohesion & \\
SBDE & financial support & \\
Government and Bank &
\end{tabular}

The primary stakeholders include farmer, millers and bakers. The main challenges to farmers are low yield of spelt and poor market access leading them to sell their spelt to the animal farm as feedstuff. For this market, on average the farmer only obtains 0.24 euro for every kilogram giving him a negative income from his spelt produce. Secondary stakeholders are the input suppliers and the service providers. The input suppliers include the seed company which usually originates from Germany, US and Russia. Roekel, a service provider which closely do transactions with the farmer provides the seeds for planting, transport of harvested grains from the farm to the grain buyer and farm machineries for land preparation and postharvest processing. And lastly, another service provider is the external laboratory which conducts the testing to determine grain quality such as the percentage protein content of the spelt grain. Tertiary stakeholders include the Stichting Buurstchap Doesburger Eng (SBDE) foundation that facilitates the sustainable restoration of the Doesburger Eng to its original status which is its primary goal of coordination of regional development. Additionally, the Municipality of Ede which is responsible in the policy making and supporting restoration of cultural heritage in the area.

\subsection{Swot Analysis of Spelt Bread}

Based on the result, the following are the strengths, weaknesses, opportunities, and threats in the spelt bread value chain in Bennekom and Wageningen.

Table 2. SWOT of spelt bread value chain.

\begin{tabular}{ll}
\hline & - Rising awareness of consumers of the usage of spelt \\
Strengths & - Willingness of the bakeries and millers to accommodate local producers \\
& - Few actors are involve in the chain \\
Weaknesses & - Short term contracts that functions like an open market. \\
Opportunities & - Nolanced value share specifically in the organic segment \\
Threats & - Intensification of suppliers competition \\
\hline
\end{tabular}

\subsection{Business Model Generation}

In order to assist stakeholders to link them into the conventional bread chain, a business model canvass is presented where they can optimize profit especially the farmer. The model presents the fundamental components of the business idea - to link the spelt farmer to the conventional spelt bread chain. The components include value proposition, key partners, key activities, key resources, customer relationships, customer segments, channels, cost structure and revenue streams.

The business model Canvas

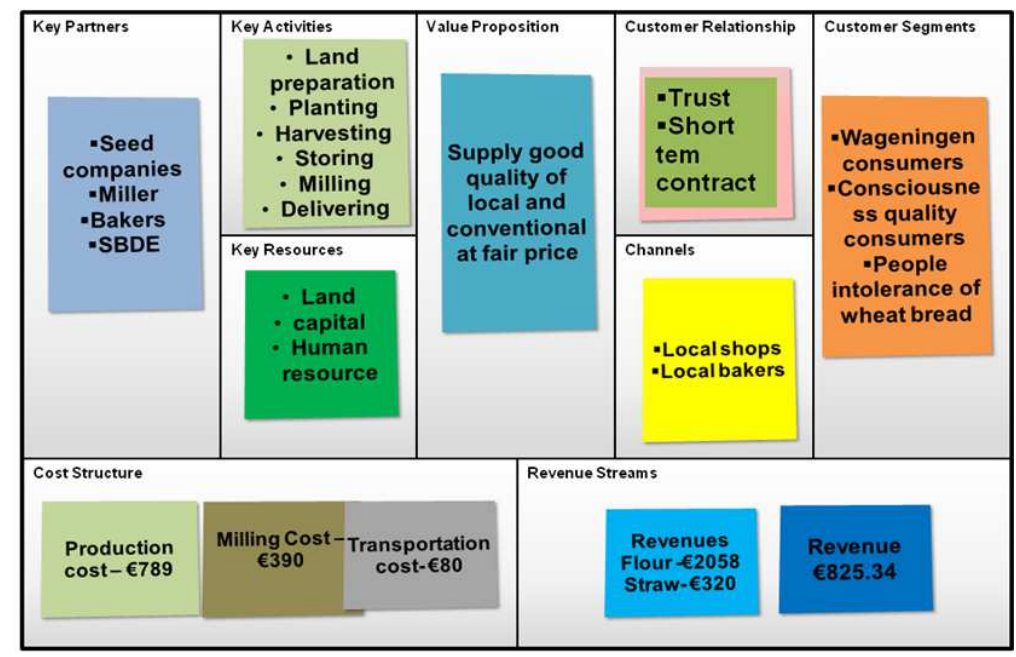

Source: www.businessmodelgeneration.com

Figure 3. Business model canvas for local conventional spelt bread inthe study area. 
The spelt bread products can be sold through the local shops in such as Joop ten Veen, Van voorthuizen, Albert Heijn, C1000, Broodbakkerij Bak and Kardoen. These shops expressed willingness to bake and sell local conventional spelt products to support local farmers. They can also promote the product through their websites emphasizing the local nature of the bread. Such promotion can likewise be done by the municipality of Ede to increase awareness of the local residents who will be the primary consumers of the product.

\section{Discussion}

\subsection{Chain Actors and Supporters}

The spelt bread value chain in Bennekom and Wageningen can be classified as a market driven chain where the amount of supply of grains or flour is dictated by bakeries based on the demand of the consumers. Although there is no local supplier of any spelt grains or conventional flour but supply from sources outside of the area are more than enough. Thus, supplying flour as a mode of entry in the chain would require a good strategy. On the other hand, since local products are gaining market shares such as in the area, this would be an opportunity for the Doesburger Eng farmer to link in the chain.

Among the actors in the chain, the millers have dual role as processor and retailers in the chain. They accept milling service or buy grains, process it, and retail in the bakeries and their shops. This means that millers do not practice exclusivity of owning the flour after milling unlike bakers who do not accept baking service. Thus, producers of grains can only own and add more value to their product after milling and supplying bakeries.

Although millers have dual role but the most powerful actor in this chain lies among bakers who have the biggest value share as computed and direct access to the consumers. This is supported by Hingley (2005) as cited by Ruben, et al (2007) that says in times of increasing scarcity of resources, the power balance may shift towards supply side, but in times of increasing abundance the power balance tends to be concentrated at the demand side. Hans (2015) also reported that, a critical asset can only be truly owned and/or controlled effectively to leverage value if there is a dominance of one party in an exchange relationship over another.

A supporter in the chain exists strongly in the organic chain. However, it does not imply that the chain has weak nor a strong support system probably because in the conventional chain it is not needed.

\subsection{Market Institutions}

\subsubsection{Contract}

A short term contract exists in both chains. This is manifested in the pre-order of grains and flour. Also pre-ordering of bread is done in the organic segments. Although there is a high opportunity for switching of partners in this type of contract however repetition of order occurs most of the time. Thus the relationship that exists among actors is based on trust and not by contract.

In both chains also, a good quality and consistent supply of flour are important requirements of the bakers towards their suppliers. In the organic segment, Skal certification is needed to certify that it is of organic quality while in the conventional chain, a baking test is required. This signifies that they are major determinants in penetrating the market and establishing a long term relationship. This idea is supported by Saenz and Ruben (2004) where guaranteeing reliable deliveries and consistent product quality are stimulus for more exclusive delivery arrangements.

\subsubsection{Quality Standards}

Every actor in the chain is aware of the importance of quality of the product. However, the only quality standard that exist in the chain is the standard of Skal for organic production. Once certified as organic, the product will bear the EKO quality mark. Actors in the chain that are Skal certified are Agrifirm, Mill de Vlijt, Stroop, and Kardoen. Although, Jop ten Veen is baking organic spelt bread but it is not certified and sells bread at the same price with Skal certified breads.

It is also interesting to know that Broodbakkerij Bak is willing to start the partnership with the farmer as long as the quality flour will be tested through baking in his bakery. Previously he was supplied with conventional wheat flour from a farmer but was stop because of bad quality of the flour.

\subsection{Consumers' Perception in Buying Spelt Bread}

The conventional spelt breads available in the shops of Bennekom and Wageningen are produced in-house but some are also delivered from main shops especially for supermarket breads. The study results revealed that Bennekom and Wageningen consumers buy spelt bread primarily because of two reasons: they patronize locally produced products and second, because of established shop reputation selling the bread. Few of the bakery shops and supermarkets selling conventional spelt bread include as Joop ten Veen, Van voorthuizen, Albert Heijn, C1000, Broodbakkerij Bak and Kardoen. However, due to certain limitations of the survey, it cannot be established which among these shops mentioned has the highest percentage of spelt bread customers.

Out of the total interviewed spelt bread consumers, (33\%) of the respondents stated that they buy spelt bread because of locally produced, (31\%) shop reputation, $(16 \%)$ health reason, $(11 \%)$ price reason and $(9 \%)$ taste reason.

\subsection{Value Shares}

Based on the computation of value shares, bakeries in both segments have the highest value shares, followed by producers and millers. Although millers have the lowest shares but since milling is done in bulk quantity thus it enjoys the advantage of economies of scale and probably has bigger gross margin than producers.

On the other hand, the value share in the organic segment 
(34\%) is higher than conventional segment (24\%) but in terms of gross income, it is opposite. Offermann and Nieberg (2007) studied the profitability of organic farming in Europe, found out that on average the profits of organic farms are very similar to those of comparable conventional farms and significant differences exist only for different farm types and regions. But in this case, there is a significant difference since this production is based on a small area only and thus transaction costs is high.

Table 3. Value shares of actors in the chain.Variable costs of millers and bakers are not shown due to unavailability of data during the interview.

\begin{tabular}{|c|c|c|c|c|c|}
\hline $\begin{array}{l}\text { Chain } \\
\text { Actors }\end{array}$ & $\begin{array}{l}\text { Variable } \\
\text { Costs (€) }\end{array}$ & $\begin{array}{l}\text { Revenue } \\
\text { (€) }\end{array}$ & $\begin{array}{l}\text { Gross } \\
\text { Income } \\
\text { (€) }\end{array}$ & $\begin{array}{l}\text { Added } \\
\text { Value } \\
\text { (€) }\end{array}$ & $\begin{array}{l}\text { Value } \\
\text { Share } \\
(\%)\end{array}$ \\
\hline \multicolumn{6}{|l|}{ Organic } \\
\hline Producer & $2.00 / \mathrm{kg}$ & $1.23 / \mathrm{kg}$ & -0.77 & 1.23 & 34 \\
\hline Miller & & $1.53 / \mathrm{kg}$ & & 0.53 & 15 \\
\hline Bakers & & 3.60/bread & & 2.07 & 57 \\
\hline \multicolumn{6}{|c|}{ Conventional } \\
\hline Producer & $0.40 / \mathrm{kg}$ & $0.60 / \mathrm{kg}$ & 0.20 & 0.60 & 23 \\
\hline Miller & & $1.00 / \mathrm{kg}$ & & 0.40 & 15 \\
\hline Bakers & & 2.60/bread & & 1.60 & 62 \\
\hline
\end{tabular}

Sources: Collected quantitative data, Skal 2013, VHL 2012

\section{Conclusions and Recommendations}

The study results revealed that the spelt bread value chain in Bennekom and Wageningen consists of organic and conventional segments. It is market driven and a short chain that only few actors are involve. Although there is no local producer within the area but the source of spelt grain in the organic chain and flour in the conventional chain are from big companies. This chain is coordinated by bakers who have direct access to the amount and kind of need in the market and have the highest value shares. Between the local and organic and conventional segments, the conventional local chain is more profitable with positive margin opposite to the organic chain which has negative margin on per hectare production basis. The relationship that exists among actors is based on trust and not on contract. The foundation of building their trust is determined by a consistent supply of good quality and amount of quantity needed.

Based on this study, it is feasible for spelt grower farmers to be linked in the existing chain through outsourcing of milling and directly supplying flour to the conventional bakery. However, in this chain where relationship is based on trust and not on contracts, the farmers should be able to fulfill the requirements of delivering consistent good quality and supply of flour throughout the year which serves as the foundation of building trust among partners in the chain. Low yield of spelt crop is other challenge to increase farmers' profit. Therefore, agricultural research and University (VHL) should give technical advice for the farmers on improving yield.

\section{Acknowledgement}

I am very thankful to my advisor Marco Verschuur for his well thought advises and guidance given throughout my study.

\section{References}

[1] Abdel,E. and Wood,P. (eds). 2005. Specialty Grains for Food and Feed. American Association of Cereal Chemists, Inc. Minnesota,USA.

[2] Business Model Generation. 2013. The Business Model Canvas. [online] Available at $<$ http://www.businessmodelgeneration.com/canvas> [Accessed 26 May 2013].

[3] Escarnot, E., Agneessens, R., Wathelet, B., Paquot,M. 2010. Quantitative and qualitative study of spelt and wheat fibres in varying milling fractions

[4] Food Chemistry, Volume 122, Issue 3, 1 October 2010, Pages 857-863. [Online] Available at http://dx.doi.org/10.1016/j.foodchem.2010.02.047. Accessed on 19 May 2013.

[5] FAO, 2003. Market research for Agro-Processors. [online] Available at $<$ http://www.fao.org/docrep/007/y4532e/y4532e07.htm\#TopO fPage $>$ [Accessed 24 May 2015].

[6] Hans W. Gottinger. Supply-Chain Coopetition. International Journal of Business and Economics Research. Vol. 4, No. 2, 2015, pp. 67-71.doi: .11648/j.ijber.20150402.16. [Online] Available at. (http://www.sciencepublishinggroup.com/j/ijber) [Accessed 10 July 2015].

[7] NC State University, 2005. Alternative Marketing Techniques. [online] Available at $<\mathrm{http} / / /$ www.organicgrains.ncsu.edu/marketing/alternativemar keting.htm $>$ [Accessed 23 May 2015].

[8] Offermann, F and Nieberg, H (2000). Profitability of organic farming in Europe. In: Alföldi, Thomas; Lockeretz, William and Niggli, Urs (Eds.) IFOAM 2000 - The World Grows Organic, Proceedings 13th International IFOAM Scientific Conference, Basel 28-31 August 2000, VDF Hochschulverlag, pp. 666-669. [Online] Available at http://orgprints.org/823/ [Accessed on 28 May 2015]

[9] Peter Kessels Dadzie, Kwasi Frimpong-Mensah, Martin Amoah, Ernest Boampong. Scenario Analysis of Profits in Further Processing Lumber to Furniture in Ghana for Export: A Case Study of a Local Firm. International Journal of Business and Economics Research. Vol. 4, No.2, 2015, pp. 55-66.doi:10.11648/j.ijber.20150402.

[10] Ruben,R., van Boekel,M., vanTilburg, A., Trienkens,J. (eds.) 2007. Tropical Food Chains. Wageningen Academic Publishers. The Netherlands

[11] Skal. 2013. Skal Rates Journal. [Online] Available at http://www.skal.nl/ [Accessed on 25 May 2015]

[12] Van Hall Larenstein (VHL) APCM students, Verschuur, M. (ed). 2012 Sustainable Cereal Business in the Doesburger Eng. Van Hall Larenstein 
[13] Village Council welcomes you Bennekom! Dorpsraad Bennekom. 2012. [Online] Available at http://www.dorpsraadbennekom.nl/ [Accessed on 25 May 2015].
[14] WHFoods, 2013. Spelt. [online] George Mateljan Foundation. Available at http://www.whfoods.com/genpage.php?tname=foodspice\&dbi $\mathrm{d}=143$ [Accessed 18 May 2015]. 